\title{
Assessment of Major Volatile and Phenolic Compounds from 'Fetească Regală' Wine Samples after Pre-fermentative Treatments using GC-MS Analysis and HPLC Analysis
}

\author{
Ana-Maria MOROȘANU ${ }^{1}$, Camelia E. LUCHIAN ${ }^{1}$, Marius NICULAUA ${ }^{2}$, \\ Cintia Lucia COLIBABA ${ }^{1}$, Alexandru C. TART, TAN ${ }^{1}$, Valeriu V. COTEA ${ }^{1 *}$
}

\author{
${ }^{1}$ University of Agricultural Sciences and Veterinary Medicine Iaşi, 3 M. Sadoveanu Alley, 700490 Iaşi, Romania; \\ morosanu.anamaria88@yahoo.ro;kamelia_luchian@yahoo.com; cintia.colibaba@gmail.com; tartianalexandru@gmail.com; \\ vvcotea@yahoo.com (*correspondingauthor) \\ ${ }^{2}$ Romanian Academy of Sciences, Center of Oenological Researches, Iași Branch, 9 M. Sadoveanu Alley, 700490 Iași, Romania; \\ niculaua@gmail.com
}

\begin{abstract}
'Fetească regală', the most cultivated white Romanian grape variety produces elegant wines with flowery notes and white fruits (especially apricot and citrus) hues, with a good acidity. Its volatile profile (esters, terpenes, higher alcohols) and phenolic compounds are of great interest to the wine industry, especially regarding the influence pre-fermentative stages have on their extraction, as most producers choose to follow this path. This study analyses how different pre-fermentative treatments (addition of bentonite, glutathione, tannins, clarifying enzymes) change the final profile of the product. The four variants are the most used prefermentative methods. A sensorial analysis of the obtained wines was performed and the obtained data was correlated with GC-MS and HPLC analysis. 25 volatile compounds were identified and quantified through headspace analysis, using different compound libraries, while through HPLC the presence and quantity of 14 major phenolic compounds was determined. Statistical analysis (One Way Anova) was applied to establish the influence of the pre-fermentative treatments on the quantitative presence of the analysed groups of compounds. The applied treatments bring changes to the final wines' profile by increasing the quantity of some phenolic compounds (gallic, protocatechic, p-hydroxybenzoic, gentisic, vanillic and caffeic acid ). From a sensorial point of view, all prefermentative treatments bring a smoother feel of obtained wines, with lower acidities and less of a 'green' character. The final results can be used by industry by adding or removing from their technological process certain steps that have influence on aroma compounds of 'Fetească regală’ wines.
\end{abstract}

Keywords: alcohols, esters, phenolic compounds, Romanian grape variety, terpenes

\section{Introduction}

Fragrance plays a key role in the food and beverage quality, since the interaction of aromatic substances with the senses of smell and taste leads to consumer acceptance or rejection. The aroma of wine is a junction between the volatile compounds of different origins: grapes, yeasts, bacterial metabolism, winemaking practices and eventually oak when used.

'Fetească regală' is a relatively new Romanian grape variety and it represents a hybrid between 'Fetească albă' and 'Grasă de Cotnari' (ancient traditional Romanian grape varieties). This variety is a semi-aromatic one and the wines obtained are characterized by elegant rose hues, with notes of wild flowers, dried apricots and almonds (Antoce and
Cojocaru, 2015). Furthermore the wines are characterized by freshness, a pleasant acidity with harmonious notes of mineral and fruity flavours, as well as honey flavour (Antoce, 2012). Still, the development of the aroma and various aromatic notes depends on the management of the winemaking process.

The great variety of volatile compounds with different polarities, volatilities and wide range of concentrations, such as: esters, terpenes, aldehydes, alcohols, etc. ensure the complexity of a wine, its character and finally helps in the process of differentiating one wine from another (Jiang and Zhang, 2010). Better understanding the chemical nature of a wine aroma demands the quantitative determination of quite a large number of different odorous active compounds (Ferreira et al., 2001). In this case, gas chromatography analysis of volatile compounds becomes an important tool 
248

useful for wine classification (Guth, 1997a, 1997b; Ferreira, 2001), quality control (Blank et al., 1997; Tominaga et al., 1998a; Mestres et al., 1998; Mestres et al., 2000) or for understanding the sensorial proprieties of a wine (Allen $e t$ al., 1994; Ebeler and Spaulding, 1998).

The phenolic compounds are secondary metabolites that are derivates of pentose phosphate, shikimate and phenylpropanoid pathways in plants (Randhir et al., 2004). Referring strictly to grapes and wines, these compounds are responsible for the development of major organoleptic proprieties, in particular: colour, astringency, flavour and the body and texture of a wine (Minussi et al., 2003). In this regard the phenolic composition of wines depends on the variety of grapes, on the winemaking process and also on the aging conditions (Cheynier et al., 1997).

Usually the literature approaches the presence and dynamic of phenolic compounds in red wines and less in white wines due to the fact that here the presence of the phenolic compounds is lower. For example the presence of catechin is more notable in red wines where this compound was identified in average amounts of $6.81 \mathrm{mg}(100 \mathrm{~mL})^{-1}$ and maximum amounts of $39 \mathrm{mg}(100 \mathrm{~mL})^{-1}$ (Frankel et al., 1995). On the other hand the presence of this compound in white wines is lower (average amount $\left.1.08 \mathrm{mg}(100 \mathrm{~mL})^{-1}\right)$ a maximum content being identified in Californian Chardonnay wines, respectively $4.60 \mathrm{mg}(100 \mathrm{~mL})^{-1}$ (Frankel et al., 1995). Another example is the presence of gallic acid that varies from an average amount of $0.22 \mathrm{mg}$ $(100 \mathrm{~mL})^{-1}$ in white wines (Minussi et al., 2003) to an average amount of $3.59 \mathrm{mg} \mathrm{mL}^{-1}$ in red wines (Kilink and Kalkan, 2003). However, the presence and the variability of these compounds in the white wines should not be disregarded.

Phenolic aldehydes (eg. vanillin), hydroxycinamic acids (e.g. caffeic, ferullic and p-coumaric acid) and their esters, flavonols, flavanols, benzoic acids (e.g. gallic acid) and anthocyanins are extracted from grapes during the winemaking process. Furthermore, in wines can be identified also the presence of flavon-3-ols, hydrolysable tannins (Martin et al., 1992; Guichard et al., 1993), stilbenes (Tominaga et al., 1998b; Ortega et al., 2001).

The style of a wine strongly depends on the intrinsic factors such as: cultivar, year of harvest, climate conditions, terroir, but also on the extrinsic factors of which the most important is the winemaking process.

The importance of this study results from a natural necessity and also from the consumer's requirements. Thus, pre-fermentative treatments are critical when the nature does not help due to the fact that grapes may not have ripened optimally or simply when personalized wines are requested according to consumer's demands.

The aim of this research was to quantify the presence of major volatile compounds and the phenolic compounds from the experimental variants of white wines after applying pre-fermentative treatments such as: bentonite, glutathione, tannins and clarifying enzymes in certain predetermined conditions and to evaluate their impact on the chemical substrate and also on the sensorial palette.

\section{Materials and Methods}

Grape samples and reagents for the pre-fermentative treatments

In order to conduct the present study a Romanian grape variety was used: 'Fetească regală. This grape variety represents one of the most popular wine grape varieties of Romania (Robinson and Harding, 2015). Generally, this indigenous grape variety is used to obtain dry white wines with a great aging potential.

The grapes were manually harvested from the Ampelographic Collection of USAMV Iasi, Copou vineyard (the NE part of Romania, latitude: 47.19487; longitude: 27.552405; altitude: 137 meters), in 2014. The raw material was processed using the classical fermentation technology for white wines as follows: after crushing and destemming, the marc was homogenized. Then a hydraulic press was used for pressing. The general physical-chemical characteristics of the 'Fetească regală' grapes and must are presented in Table 1.

In the pre-fermentative stage, the grape must variants were submitted to different treatments, as follows: FRV0 no treatment was applied, FRV1 - treatment with bentonite - clay on the must, FRV2 - treatment with glutathione on the must in fermentation, FRV3 -treatment with tannins on the marc and a short maceration applied (24 hours), FRV4 - clarifying enzymes treatment on the marc and a short maceration applied ( 24 hours). The pomace obtained after crushing the mark was homogenized and divided and added back in the five $15 \mathrm{~L}$ demi-johns for the rest of the alcoholic fermentation process.

In the case of the control sample, the marc obtained from 'Fetească regală' grapes was pressed using a hydraulic press, at a pressure of two bars.

In the initial stage, fermentation activators were added in a quantity of $7 \mathrm{~g}$ at $15 \mathrm{~L}$ of must and the addition of selected yeasts was then carried out in amount of $5 \mathrm{~g}$ at $15 \mathrm{~L}$ of must. The yeasts were rehydrated before using.

The obtained must was stored in $15 \mathrm{~L}$ demi-johns, ensuring the necessary headspace for the fermentation. The fermentation lasted 10 days under controlled temperature conditions of $15-18^{\circ} \mathrm{C}$, avoiding direct contact with air.

The wines were racked, conditioned and filtered using the Grifo with cellulose filter plates (SA-995, Sodinal, France). In the last stage, $1 \mathrm{~mL}$ of $\mathrm{SO}_{2}$ (conc. 5\%) was added at $750 \mathrm{~mL}$ of wine before bottling with a semiautomatic bottling machine.

In the case of FRV1, the wine samples were obtained using an identical process to the one described above. The addition of bentonite was made within 24 hours after the must started its fermentation. Bentonite was added as bentonite milk in quantity of $210 \mathrm{ml}$ at $15 \mathrm{~L}$ of must in fermentation, thereby providing a greater clarification and deproteinization. The must was homogenized to provide the best possible dispersion of bentonite in the medium.

For the sample FRV2, the addition of glutathione was done after must settling. $5.25 \mathrm{~g}$ of glutathione were added after a pre-dilution of the product in the must for a more efficient homogenization. The product that was used is mixture of glutathione and gallic tannin, one gram of product producing $6 \mathrm{mg}$ of glutathione. The product favored the development of aromatic expression and increased structure and volume, and by its oxygen affinity 
glutathione protects the aromatic notes of young wines and prevents their early oxidation.

For the sample FRV3, the marc resulting from the destemming and the partial crushing was introduced into 30 $\mathrm{L}$ vessels, with the addition of 5 g oenological tannin per $25 \mathrm{~L}$ of marc. The sample was subjected to maceration process for 24 hours and then pressed.

For the sample FRV4, marc was introduced into $30 \mathrm{~L}$ vessels and treated with clarifying enzymes. In order to carry out the proposed treatment, a standardized product was used, adding $0.75 \mathrm{~g}$ of enzymes to 25 liters of marc. The product contained a high concentration of pectolytic enzymes that provides fast static clarification of the marc, even under low temperature conditions, by hydrolyzing pectins and reducing the viscosity of the marc. The marc was homogenized and left to macerate for 24 hours, then pressed. The resulting must was transferred into $15 \mathrm{~L}$ glass vessels.

Before analysis, the samples were then submitted to the decarbonatation process and were analysed regarding the alcoholic strength, total acidity, volatile acidity, non-reductive extract, reductive extract, free and total $\mathrm{SO}_{2}$, according to the OIV methods.

Gas-chromatographic quantification of volatile compounds In order to assess the aroma fraction, a HS20-GC-MS (head space extractor coupled to gas chromatography with mass spectrometer) was used. The system used as carrier gas the helium and the adsorption material for the stationary phase was a resin 2, 6-diphenylene oxide (TENAX).

A headspace method was used: $7 \mathrm{~mL}$ of wine were added in a vial. All samples were heated up to $70{ }^{\circ} \mathrm{C}$ and shaken $(25$ rpm for 5 minutes). The vials were pressurized to $60 \mathrm{KPa}$ with helium to remove condense. The volatile fraction was transferred into a Tenax trap at $-10{ }^{\circ} \mathrm{C}$ by a transfer line at $150^{\circ} \mathrm{C}$. Before injection, for half a minute the trap was dry purged and then the volatiles were transferred at $280^{\circ} \mathrm{C}$ with a split of $1 / 50$ into the analytic column.

The separation column used was a Phenomenex Zorbax FFAP type $50 \mathrm{~m} \times 0.32 \mathrm{~mm}$ ID $\times 0.5 \mu \mathrm{m}$ which was kept at a starting temperature of $82{ }^{\circ} \mathrm{C}$. After $3 \mathrm{~min}$ of isothermal condition (transfer load and equilibration of pressure between head space device and GC oven), the temperature increased by $3{ }^{\circ} \mathrm{C}$ min. $^{-1}$ up to $135^{\circ} \mathrm{C}$, maintaining this plateau for 1 minute, then by $7.5^{\circ} \mathrm{C} \mathrm{min.} .^{-1}$ up to $160{ }^{\circ} \mathrm{C}$, maintained for 1 minute and finally by $27^{\circ} \mathrm{C} \mathrm{min}^{-1}$ to 240 ${ }^{\circ} \mathrm{C}$, remaining constant for 8 minutes (total temperature program 37 minutes). Separation was carried-out at a constant linear velocity of $35 \mathrm{~cm} \mathrm{~s}^{-1}$ (column flow $1.5 \mathrm{~mL}$ $\min ^{-1}$ at start-up).

The 8040 MS triple quadrupole was used in Q3 (third quadrupole) scan mode (TIC) from $30-400 \mathrm{Da}$ at $0.1 \mathrm{~s}$ event time $\left(5000\right.$ scan $\left.\mathrm{sec}^{-1}\right)$. The ion source interface was maintained at $230{ }^{\circ} \mathrm{C}$ and source at $200{ }^{\circ} \mathrm{C}$. The molecules were ionized by electron impact (EI) at $70 \mathrm{eV}$.

The results were processed qualitatively comparing them to different MS databases available: NIST 14, Wiley 10, FFNSC and SZTERP. For the quantitative results, all samples were processed by relative response to an internal standard of 4-methyl-pentan-2-ol. The chromatograms of the blank sample and of the wine samples analysed are presented in Fig. 6 and the fragmentation for the compounds is presented in Table 6.
HPLC-analysis of the phenolic compounds

The analysis of the phenolic acids was carried out using a high performance liquid chromatography technique. In this sense a liquid chromatography Shimadzu series Proeminence LC20 was used.

The chromatographic column presented has a precolumn Phenomenex Security- Guard Ultra cartridge UHPLC C18 for the column that has a $4.6 \mathrm{~mm}$ diameter, same as the analytical column.

The particles in the column were made by Fused-Core type technology presenting a solid silica core of $2.25 \mu \mathrm{m}$ and adsorption layer of $0.35 \mu \mathrm{m}$ that were with $85 \%$ more efficient with high resolution and low counter pressure system. Separation was achieved through a Kinetex column produced by Phenomenex Inc. having the following characteristics: $150 \times 4.6 \mathrm{~mm}$ stainless steel, loaded with particles of silan grafted with an octadodecil (C18), $96 \AA$ pores diameter and having a graft capacity of $3 \mu \mathrm{mol}\left(\mathrm{m}^{2}\right)^{-1}$.

The separation of compounds was obtained with a mixture of solvents:

$>$ eluent A: $0.1 \%$ solution of methanol $\left(\mathrm{CH}_{3} \mathrm{OH}\right)$ acidified with trifluoracetic acid (TFA) at a $\mathrm{pH}$ of 2.17;

$>$ eluent B: $50 \%$ solution of methanol $\left(\mathrm{CH}_{3} \mathrm{OH}\right)$ acidified with trifluoracetic acid (TFA) at a $\mathrm{pH}$ of 2.22 .

The autosampler was kept at $0{ }^{\circ} \mathrm{C}$ and $10 \mu \mathrm{L}$ of sample previously filtered through a nylon filter with pore size of $0.45 \mu \mathrm{m}$ was injected into the separation system.

The elution was done in the column oven at $50{ }^{\circ} \mathrm{C}$ following a gradient program: $0 \% \mathrm{~B}$ at the start maintained for 3 minutes, linear increase to $18 \% \mathrm{~B}$ until minute 11 , then $30 \% \mathrm{~B}$ until minute $19,35 \% \mathrm{~B}$ until minute $25,60 \% \mathrm{~B}$ until minute 33 , maintained at $60 \% \mathrm{~B}$ until minute 38 , linear increased to $80 \% \mathrm{~B}$ until minute $43,100 \% \mathrm{~B}$ until minute 46 , maintained until minute 50 , then linear recovery to $0 \% \mathrm{~B}$ in 3 minutes and re-equilibration for 7 minutes. The system flow is $0.85 \mathrm{~mL} \mathrm{~min}^{-1}$, which developed back-pressure ranging from 175 bar to 290 bar.

The system detector was a DAD (diode array detector) with a speed scan of $6.25 \mathrm{~Hz}$ between 190-600 nm for an 8 $\mathrm{nm}$ slit aperture. The analysis for protocatehic acid, phydroxybenzoic acid, vanilic acid was done at $256 \mathrm{~nm}$. In the case of gallic acid, syringic acid, epicatechin, catechin, ferulic acid the $280 \mathrm{~nm}$ wavelength was chosen. Finally for the: gentisic acid, caffeic acid, clorogenic acid, p-coumaric acid, sinapic acid, trans-resveratrol and quercetin, the majority of maximum spectral absorbance is around 324 $\mathrm{nm}$. In the Fig. 7 are presented the chromatograms for the blank sample and for the wine samples.

\section{Reagents}

Reagents for the pre-fermentative treatments

In what concerns the pre-fermentative treatments the following reagents were used: Bentonite Clarit 360 from Sodinal (France) (for the sample treated with bentonite), Mannoblanc from Agrovin (Spain) (for the glutathione treatment), Taniblanc from Sodinal (France) (for the tannin treatment) and Zymoclaire CG from Sodinal (France) (for clarifying enzymes treatment). Furthermore, in the winemaking process there were used: fermentation 
activators - Fermoplus Integrateur from Sodinal (France) and selected yeasts Fermactive AP from Sodinal (France).

\section{Reagents for GC-MS analysis}

In this case, a standard solution 4-methyl-2-pentanol (assay 98\%) from Merk Chemicals GmBH (Germany) was used. All the others commercial substances and reagents were provided by Sigma Aldrich (USA), as in detailed in the Annex 1.

\section{Reagents for the HPLC analysis}

The mixture of solvents used for the separation of compounds was provided from Sigma Aldrich (USA), respectively methanol (assay- 99.8\%) and trifluoracetic acid (assay- $\geq 99 \%$ ). The other reagents for the HPLC analysis were also provided from Sigma Aldrich (USA) and were presented bellow in Annex 1.

\section{Sensorial analysis}

The wine samples were assessed for aroma and flavor acceptability by 10 tasters according with the evaluation method originally proposed by the International Union of Oenologists - organoleptic evaluation of aroma parameters through the "closed" tasting method and recording them on a chart tasting. The tasters evaluated specific characteristics of the wines with ratings from 0 to 10 (Annex 2). The final score was calculated as the mean of all the results, taking into account the evaluation of each taster.

\section{Statistical analysis}

In order to determine the influence of the applied treatments on the analysed compounds (esters, terpenes, alcohols and phenolic compounds) a one way ANOVA test was applied. The test was done with the SPSS17 with the aim to determine whether there are any statistically significant differences between the means of the groups. The independent variable was represented by the applied treatments and the phenolic compounds identified were considered as the dependent variable. The reference significance $\alpha$ value of the test was 0.05 with a confidence level of $95 \%$ and two hypotheses were created: the null hypothesis that the treatments didn ' $t$ affected the chemical and sensorial structure of the wine sample and the alternative one that in fact the treatments did affect the structure of the analysed wines.

\section{Results and Discussion}

Basic physic-chemical parameters of the analysed wine samples

The basic physic-chemical parameters of the analysed wines are presented in Table 2 and it is immediately noticed that the wine cannot be considered a quality wine. A possible cause might be the grapes, whose qualitative characteristics show that the raw material was not harvested at technological maturity (Table 1).

The alcoholic strength has varied from a minimum of $7.7 \%$ in the control sample and a maximum of $9.58 \%$ for the sample treated with bentonite-clay. The values of the total acidity were high for all the samples, the maximum value being in the sample treated with glutathione: $9.13 \mathrm{~g} \mathrm{~L}^{-1}$ tartaric acid (Table 2).

Regarding the volatile acidity the limits of variability were rather small, between a minimum of $0.16 \mathrm{~g} \mathrm{~L}^{-1}$ acetic acid for the sample treated with bentonite) and a maximum of $0.26 \mathrm{~g} \mathrm{~L}^{-1}$ for the control sample (Table 2). The reductive substances showed a rather high dynamic, the values of this parameter varying from a minimum of $0.44 \mathrm{~g} \mathrm{~L}^{-1}$ for the bentonite sample to a maximum of $32.11 \mathrm{~g} \mathrm{~L}^{-1}$ for the control sample. In this case, the high value recorded for the control sample suggested an incomplete metabolism of the sugars by the yeasts, so an incomplete fermentation process. As expected, the values of non-reductive extracts and reductive extracts were higher for the control sample and lower for the other samples. Relative density followed the pattern of variation of the reductive substances, the maximum value being registered in the control sample (1.0672).

\section{GC-MS analysis of esters, terpenes and alcohols}

Taking into account that aldehydes and ketones are present in particular in grape must during fermentation and are subjected to oxidation and converted into acids at the end of the fermentation process, but also that the analyzes were performed on the final product (wine after the fermentation process), these groups of compounds were not considered in the present study.

The esters are flavour compounds that occur widely in a variety of food products (Gatfield, 1992). In the fermented beverages such as wine, as a group, these compounds might be considered major constituents after water, ethanol and

Table 1. Basic physico-chemical parameters of the 'Fetească regală' grapes and must

\begin{tabular}{cccccc}
\hline Grape variety & $\begin{array}{c}\text { Total acidity }\left(\mathrm{g} \mathrm{L}^{-1}\right. \\
\left.\mathrm{C}_{4} \mathrm{H}_{6} \mathrm{O}_{6}\right)\end{array}$ & Sugars $\left(\mathrm{g} \mathrm{L}^{-1}\right)$ & $\begin{array}{c}\text { Volumetric mass at } \\
2{ }^{\circ} \mathrm{C}\end{array}$ & Gluco-acidic index & $\begin{array}{c}\text { Potential alcoholic } \\
\text { strength }(\% \text { vol. alc. })\end{array}$ \\
\hline 'Fetească regală’ & 10.92 & 158.1 & 1.0685 & 14.47 & 9.3 \\
\hline
\end{tabular}

Table 2. Parameters of wines obtained through different pre-fermentative treatments

\begin{tabular}{ccccccccccccc}
\hline Sample & 1 & 2 & 3 & 4 & 5 & 6 & 7 & 8 & 9 & 10 & 11 \\
\hline FRV0 & 7.7 & 8.6 & 0.26 & 32.11 & 202.8 & 170.6 & 20.43 & 91.97 & 1.0672 & 2.91 & 1639 \\
FRV1 & 9.58 & 8.36 & 0.16 & 0.44 & 13.7 & 13.26 & 18.27 & 59.76 & 0.9923 & 2.97 & 1688 \\
FRV2 & 9.25 & 9.13 & 0.17 & 1.58 & 19.8 & 18.22 & 38.39 & 87.32 & 0.9950 & 2.90 & 1707 \\
FRV3 & 9.18 & 8.48 & 0.16 & 1.71 & 19.3 & 17.59 & 52.02 & 111.79 & 0.9957 & 2.99 & 1794 \\
FRV4 & 9.34 & 8.48 & 0.19 & 2.01 & 19.6 & 17.52 & 29.72 & 75.87 & 0.9958 & 3.14 & 1670 \\
\hline
\end{tabular}

(\% vol. alc.); 2 - Total acidity $\left(\mathrm{g}\right.$ tartaric acid $\left.\mathrm{L}^{-1}\right) ; 3$ - Volatile acidity $\left(\mathrm{g}\right.$ acetic acid L $\left.\mathrm{L}^{-1}\right) ; 4$ - Reductive substances $\left(\mathrm{g} \mathrm{L}^{-1}\right) ; 5$ - Total extract $\left(\mathrm{g} \mathrm{L}^{-1}\right) ; 6$ - Non reductive extract $\left(\mathrm{g} \mathrm{L}^{-1}\right) ;$ 7-Free $\mathrm{SO}_{2}\left(\mathrm{mg} \mathrm{L}^{-1}\right) ; 8$ - Total $\mathrm{SO}_{2}\left(\mathrm{mg} \mathrm{L}^{-1}\right)$; 9- Relative density; 10- $\mathrm{pH}$; 11 - $\mathrm{Conductivity}\left(\mu \mathrm{S} \mathrm{cm}^{-1}\right)$ 
fusel alcohols and are the primary source of fruity aromas (Etievant, 1991).

The esters present in wine can be classified in two groups, those formed enzymatically and those formed during wine aging, by chemical esterification between alcohol and acids at low pH (Margalit, 1997). The present study focused on the research of the first group of esters, those formed enzymatically. As expected in young wines, the fruity-flowery aroma esters have prevailed. Among the esters identified using headspace analysis are ethyl hexanoate, ethyl benzoate, ethyl octanoate, ethyl myristate, ethyl palmitate.

The ethyl hexanoate, a volatile ester produced during fermentation process by yeasts, varied from a minimum of $0.03 \mathrm{mmol} \mathrm{L}^{-1}$ in the samples treated with tannin and glutathione to a maximum of $0.05 \mathrm{mmol} \mathrm{L}^{-1}$ for the control sample and the sample treated with clarifying enzymes. Ethyl caprate, an ester specific for the alcoholic beverages characterized by the fruity, apple notes (Mosciano, 1990) revealed an interesting variability in the analysed samples. As it can be observed from figure 3 the maximum quantity was identified in the control sample $\left(7.29 \mathrm{mmol} \mathrm{L}^{-1}\right)$, but in samples subjected to the pre-fermentative treatments, the amount of this compound decreased by half.

The ethyl octanoate, an ester resulting from the fatty acid degradation process and characterized by soapy, floral notes (Berger, 2007) has reached maximum concentrations in the samples treated with bentonite and clarifying enzymes, the lower concentrations being registered in the sample treated with glutathione $\left(6.55 \mathrm{mmol} \mathrm{L}^{-1}\right)$. The presence of ethyl caprate and ethyl octanoate in higher concentrations compared to other identified esters might be explained by the temperatures during fermentation.

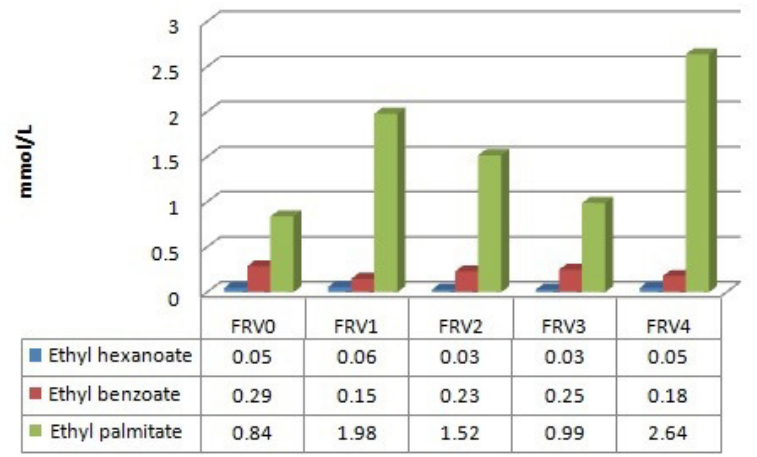

Fig. 1. Ethyl hexanoate, ethyl benzoate and ethyl palmitate in the analyzed wine samples

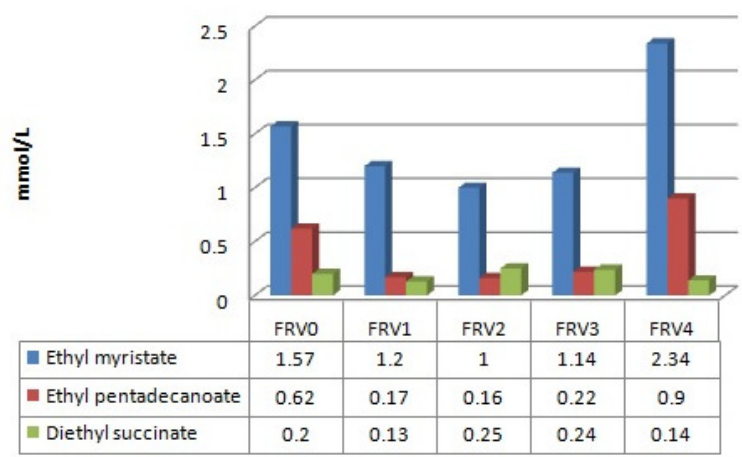

Fig. 2. Ethyl myristate, ethyl pentadecanoate and diethyl succinate in the analyzed wine samples
The ethyl lactate, an ester resulting from the cellular carbon metabolism (Hui, 2007) was identified in all the analysed samples. The pre-fermentative treatments induced an important decrease in the concentration of this compound (Fig. 3), the only exception being the sample treated with clarifying enzymes. In this case, an increase relative to the control sample was recorded. Following the dynamics of ethyl myristate in the experimental samples, the same variation model can be observed as in the case of ethyl lactate.

The analysis of the studied wine samples revealed also the presence of other esters such as: ethyl pentadecanoate, ethyl palmitate, diethyl succinate. Diethyl succinate is an ester characterized by aromatic notes of apple, ylang, cooked-like aroma and it is often present in the fermented beverages that have aged a long time (Dragone et al., 2008). The presence of this compound in the studied samples suggested the presence of a premature aging process, atypical aging.

Literature underlines the fact that the terpenoid compounds play a significant role in varietal wine aroma because of their characteristic fruity flowery odour (Camara et al., 2004; Feng et al., 2015). The presence of these odoriferous compounds depends mainly on the grapes variety and also on the winemaking process. Even if some terpenoid compounds can be found in larger quantities in some grapes varieties, it can be implied that each grape variety has specific volatile compounds (Slegers et al., 2015). Moreover the personality of each wine is due to the infinitely varied combinations and concentrations of the various volatile compounds (Ribéreau-Gayon et al., 2006). Referring to 'Fetească regală' wine samples, several terpenoid compounds were identified: linalool, $\alpha$-terpineol, geraniol, nerolidol, ho-trienol. As regard to linalool, nerolidol and geraniol the application of pre-fermentative treatments had a negative impact and decreased the concentration of these compounds (Fig.4).

Alcohols and especially higher alcohols (those containing four to ten carbon atoms) are quantitatively the largest group of aroma compounds in alcoholic beverages and are secondary products of alcoholic fermentation (Lambrechts and Pretorius, 2000). These alcohols are also known as fusel alcohols and have a strong, pungent smell and taste with an important influence on the character of a wine and in the right concentration contributes definitely to the complexity of a wine (Moss, 2015).

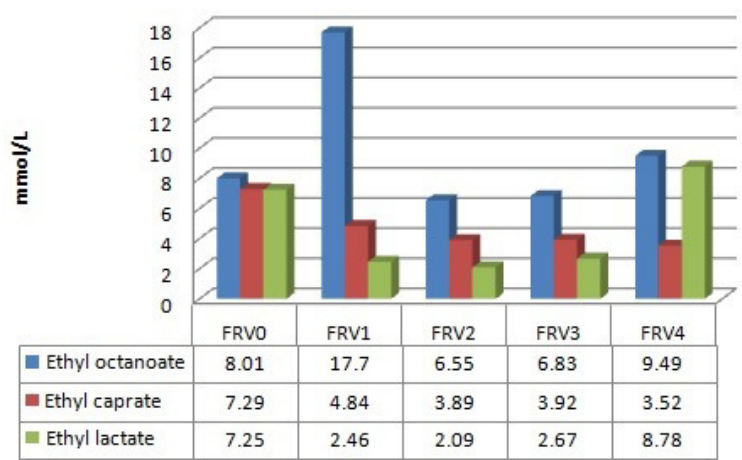

Fig. 3. Ethyl octanoate, ethyl caprate and ethyl lactate in the analyzed wine samples 


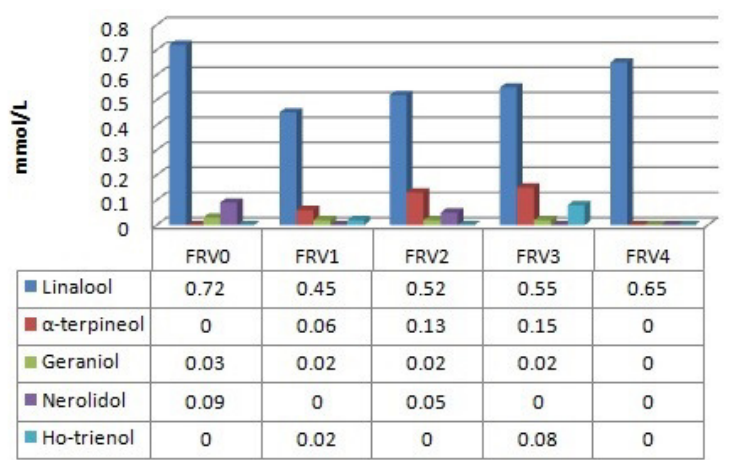

Fig. 4. Terpenoid compounds in the analyzed wine samples

Table 3. Alcohols identified in the analyzed wine samples

\begin{tabular}{llllll}
\hline Compound $\left(\mathrm{mmol} \mathrm{L}^{-1}\right)$ & FRV0 & FRV1 & FRV2 & FRV3 & FRV4 \\
\hline Propan-1-ol & 0.15 & 0.31 & 0.29 & 0.24 & 0.40 \\
Pentan-1-ol & 0.28 & 0.10 & 0.04 & 0.04 & 0.09 \\
Hexan-1-ol & 1.73 & 0.00 & 0.69 & 1.03 & 0.00 \\
Hexan-3-ol & 0.05 & 0.05 & 0.07 & 0.08 & 0.00 \\
Glycerol & 1.07 & 0.79 & 0.37 & 0.25 & 0.32 \\
Dodecan-1-ol & 0.11 & 0.04 & 0.07 & 0.03 & 0.18 \\
Hexandecan-1-ol & 0.93 & 0.65 & 0.72 & 0.80 & 2.01 \\
Decan-1-ol & 0.08 & 0.06 & 0.07 & 0.08 & 0.07 \\
Octan-1-ol & 0.09 & 0.18 & 0.08 & 0.12 & 0.09 \\
2,3-butandiol & 0.05 & 0.08 & 0.03 & 0.01 & 0.02 \\
Izobutanol & 1.40 & 1.22 & 1.03 & 1.13 & 0.93 \\
\hline
\end{tabular}

The quantitative presence of the alcohols in the wines depends on the yeast strains used and also on the raw material (grapes) and by default on the viticulture conditions (Giudici et al., 1990).

Regarding the studied samples, the qualitative and quantitative alcohols are presented in Table 3. Propan-1-ol is an alcohol whose presence in wine is directly dependent on the action of the yeast strain, the incapacity of yeasts to produce hydrogen sulfides and also on the metabolism of methionine and threonine (Lambrechts and Pretorius, 2000). In the present study, it can be observed that the prefermentative treatments didn't affect the presence of propanol in the samples, but on the contrary the application of these treatments determined a quantitative increase of this compound. On the other hand, the presence of 1pentanol was strongly influenced by the treatments since their application caused an important decrease from a maximum of $0.28 \mathrm{mmol} \mathrm{L}^{-1}$ for the control sample to a minimum of $0.04 \mathrm{mmol} \mathrm{L}^{-1}$ for the samples treated with glutathione and tannins. This variation might be explained by the fact that the production of higher alcohols is somehow increased by the media in which solid suspensions are present. In addition it might be possible of having large suspensions in larger quantities which facilitated the formation of higher alcohols.

Another important group of higher alcohols is the group of C6 alcohols which derives from the grape polyunsaturated fatty acids (linoleic acid) and gives the herbaceous smell of wines and they are a marker for wine origin (Nykanen, 1986). At concentrations below $300 \mathrm{mg}$ $\mathrm{L}^{-1}$, higher alcohols can contribute to the desirable complexity of wine, but when their concentrations exceed $400 \mathrm{mg} \mathrm{L}^{-1}$, they are regarded as having a negative effect on quality (Falqué et al., 2001). In the studied samples the presence of hexan-1-ol and hexan-3-ol was recorded. The importance of these two alcohols results from the fact that they are considered markers for assessment of wine origin (Oliveira et al., 2006) and they are formed during prefermentative stages including harvesting, crushing and pressing, as well as during must heating or grape maceration (Oliveira et al., 2006). In the present study hexan-1-ol ranged from a minimum of $0.69 \mathrm{mmol} \mathrm{L}^{-1}$ for the sample treated with glutathione to a maximum of $1.93 \mathrm{mmol} \mathrm{L}^{-1}$ in the control sample, while, in the samples treated with bentonite and clarifying enzymes, it was under the detection limit. On the other hand the presence of hexan-3-ol was detected almost in every sample, except in the sample treated with clarifying enzymes. The quantitative presence of this compound varied from a minimum of $0.05 \mathrm{mmol} \mathrm{L}^{-1}$ in the control sample and the sample treated with bentonite and a maximum of $0.08 \mathrm{mmol} \mathrm{L}^{-1}$ in the sample treated with tannins.

Glycerol is another important alcohol, a non-volatile compound which has no aromatic proprieties, but which significantly contributes to wine quality by providing sweetness and fullness (Orlic et al., 2009). This compound is one of the most important by-products of alcoholic fermentation. Referring to the studied wine samples the largest amount was identified in the control sample (1.07 mmol $\left.\mathrm{L}^{-1}\right)$, the pre-fermentative treatments applied resulting in a quantitative decrease of more than a half of the initial amount. However, in this case glycerol was a product that has resulted from the catalytic oxidation from the analytical column.

\section{HPLC analysis of phenolic compounds}

More than 10 phenolic compounds have been identified, both non-flavonoids and flavonoids. Nonflavanoids compounds include: benzoic acids (vanillic acid, gallic acid, protocatechuic acid, gentisic acid, syringic acid), cinnamic acids ( $p$-coumaric acid, ferulic acid, caffeic acid). Regarding the flavonoid compounds in the studied samples, the following groups of compounds were identified: flavonols (quercitin), flavan-3-ols (epicatechin). In addition trans- resveratrol was identified.

Gallic acid, a phenolic compound largely derived from grape seeds and stems as well as contact with oak during fermentation process (Jordão et al., 2001; Cheynier, 2005) in the analysed samples has varied from a minimum of 19.36 $\mathrm{mg} \mathrm{L} \mathrm{L}^{-1}$ for the sample treated with glutathione to a maximum of $79.88 \mathrm{mg} \mathrm{L}^{-1}$ in the sample treated with clarifying enzymes. This variation might be explained by the fact that the sample FRV4 (clarifying enzymes) was submitted to a short maceration ( 24 hours) that permitted the extraction of this compound from seeds and stems. In terms of p-hydroxybenzoic acid, it decreased by half with the application of pre-fermentative treatments compared with the control sample.

The pre-fermentative treatments with tannins and clarifying enzymes and short maceration resulted in a significant increase in gentisic acid content, even double compared to its concentration in the control sample (from $45.37 \mathrm{mg} \mathrm{L}^{-1}$ to $\left.89.75 \mathrm{mg} \mathrm{L}^{-1}\right)$. The same pattern of variation could also be identified in the case of vanillic acid, tannins and clarifying enzymes treatments, all resulting in 
an increase of up to five times the content of this compound relative to the control sample.

Caffeic acid, a compound that reaches modest levels in red wines (18.8 $\left.\mathrm{mg} \mathrm{L}^{-1}\right)$ (Schwarz et al., 2004) has recorded an important increase after applying the tannin treatment, from a value of $19.49 \mathrm{mg} \mathrm{L}^{-1}$ in the control sample to a value of $233.46 \mathrm{mg} \mathrm{L}^{-1}$ in the tannin treatment sample. The bentonite treatment and clarifying enzymes treatment determined a decrease in half. Ferulic acid and p-coumaric acids show a slight increase in concentration after the application of pre-fermentative treatments. Glutathione and clarifying enzymes treatments have led to an increase in quercitin while, for the samples with bentonite treatment the presence of this compound was under the detection limit. From the group of flavon-3-ols only epicatechin was identified. This compound did not undergo major variations after applying pre-fermentative treatments and compared with the control sample.

\section{Sensorial analysis}

Fig. 5 shows that all the wines samples had a high level of acidity, a statement sustained by the total acidity values of the analyzed samples that were presented in Table 2 . In the organoleptic charts it can be observed that in all wine samples prevailed the green/vegetable, green fruits and citric flavours. Compared with the control sample the mineral flavour was better expressed in the sample treated with glutathione and the bitter taste was expressed more intensely in the sample treated with clarifying enzymes. This is usual since the using of enzymes in the modern winemaking determines the increase of phenolic compounds. The idea is supported by the HPLC analysis of the phenolic compounds presented in Table 4, with higher
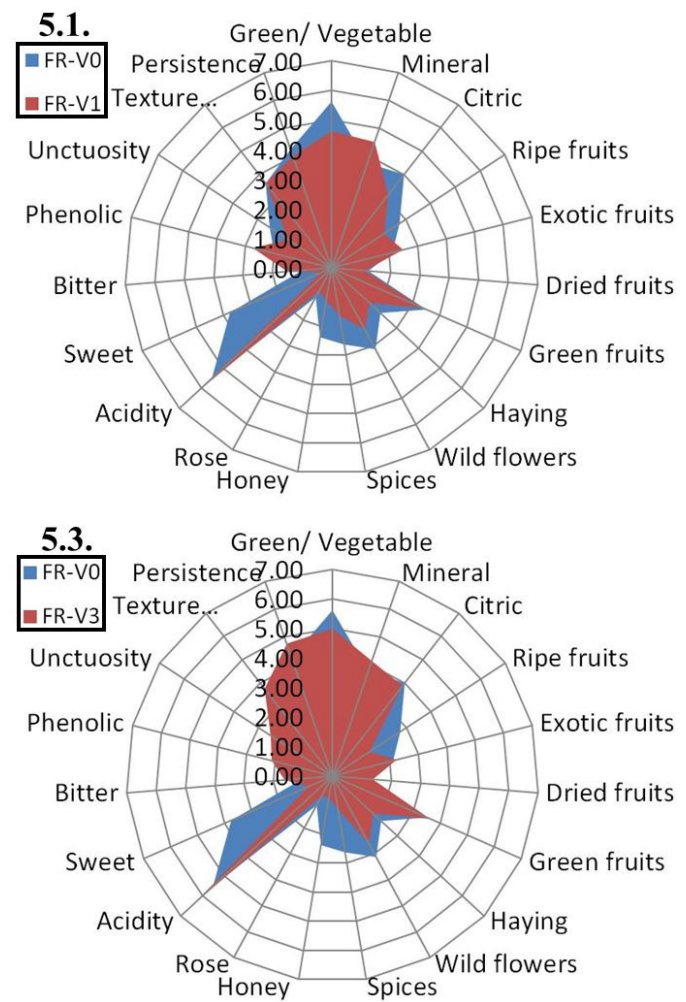

values for gallic acid, protocatechuic acid, gentisic acid and vanillic acid. The higher values of ethyl myristate could have caused the prevalence of wild flowers flavour in the sample treated with clarifying enzymes.

\section{Statistical analysis}

Concerning the statistical analysis of the esters, there were obtained alpha $(\alpha)$ values lower than the reference value 0.05 (Table 5 ) in the case of ethyl benzoate, ethyl palmitate, ethyl myristate, ethyl octanoate, ethyl caprate and ethyl lactate. Therefore, in this case the null hypothesis is rejected, the results being statically significant.

In the case of terpenes a higher value of alpha criteria than the reference value $(0.05)$ (Table 5$)$ was obtained for the linalool, so the null hypothesis is accepted and the result was not statically significant. On the other hand for the others terpenes identified the values of alpha criteria were lower than 0.05 meaning that the null hypothesis is accepted and the results are statistically significant.

Regarding the alcohols higher values than 0.05 (Table 5) were obtained for pentan-1-ol and decan-1-ol. In these cases the null hypothesis is accepted. For the others alcohols identified, the values of $\alpha$ were lower than 0.05 , so the null hypothesis is rejected and the results are statistically significant.

In what concerns the phenolic compounds, the null hypothesis is accepted in the case of ferulic acid, transresveratrol and quercitin $(\alpha>0.05)$ (Table 5). For the gallic acid, protocatechuic acid, p-hidroxibenzoic acid, caffeic acid, clorogenic acid, syringic acid, epicatechin, p-coumaric acid, sinapic acid the values of alpha $(\alpha)$ were lower than 0.05 , therefore the null hypothesis is rejected, being accepted the alternative hypothesis.
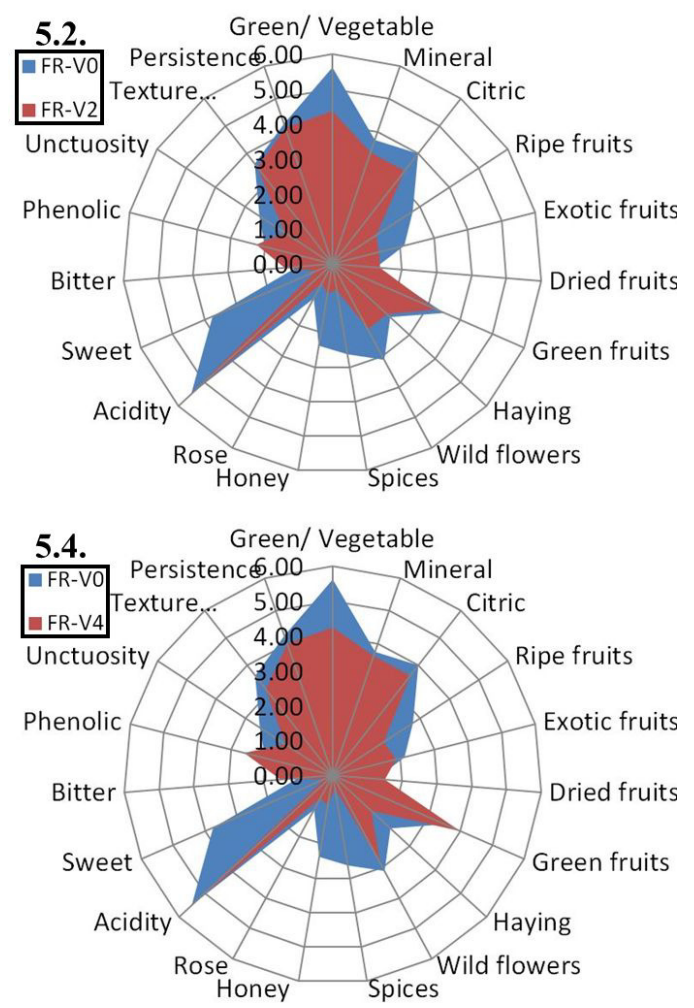

Fig. 5. Comparative organoleptic charts of the analysed samples (organoleptic chart of the control sample and the sample treated with: 5.1. bentonite; 5.2. glutathione; 5.3. tannins; 5.4. clarifying enzymes) 
254

Table 5. Results of Anova statistical analysis

\begin{tabular}{|c|c|c|c|c|c|c|c|}
\hline Compounds & $\begin{array}{c}\text { Type III Sum of } \\
\text { Squares }\end{array}$ & $\mathrm{df}$ & Mean Square & $\mathrm{F}$ & Significance & Rsquared & $\begin{array}{l}\text { Rsquared } \\
\text { adjusted }\end{array}$ \\
\hline Ethyl hexanoate & $0.02^{\mathrm{a}}$ & 4 & 5.733 & 2.324 & 0.127 & 0.482 & 0.275 \\
\hline Ethyl benzoate & $0.35^{\mathrm{a}}$ & 4 & 0.08 & 21.900 & 0.000 & 0.898 & 0.875 \\
\hline Ethyl palmitate & $6.573^{\mathrm{a}}$ & 4 & 1.643 & 145.774 & 0.000 & 0.983 & 0.976 \\
\hline Ethyl myristate & $3.483^{\mathrm{a}}$ & 4 & 0.870 & 81.573 & 0.000 & 0.970 & 0.958 \\
\hline Diethyl succinate & $0.41^{\mathrm{a}}$ & 4 & 0.010 & 3.018 & 0.071 & 0.547 & 0.366 \\
\hline Ethyl octanoate & $255.203^{a}$ & 4 & 63.801 & 113.922 & 0.000 & 0.979 & 0.970 \\
\hline Ethyl caprate & $28.153^{\mathrm{a}}$ & 4 & 7.038 & 31.787 & 0.000 & 0.927 & 0.898 \\
\hline Ethyl lactate & $117.619^{\mathrm{a}}$ & 4 & 29.315 & 1406.682 & 0.000 & 0.998 & 0.998 \\
\hline Linalool & $0.136^{\mathrm{a}}$ & 4 & 0.034 & 2.614 & 0.099 & 0.511 & 0.316 \\
\hline$\alpha$-terpineol & $0.060^{\mathrm{a}}$ & 4 & 0.015 & 19.618 & 0.000 & 0.887 & 0.842 \\
\hline Geraniol & $0.001^{\mathrm{a}}$ & 4 & 0.000 & 4.115 & 0.032 & 0.622 & 0.471 \\
\hline Nerolidol & $0.020^{\mathrm{a}}$ & 4 & 0.005 & 33.455 & 0.000 & 0.930 & 0.903 \\
\hline Ho-trienol & $0.014^{\mathrm{a}}$ & 4 & 0.004 & 180.000 & 0.000 & 0.986 & 0.981 \\
\hline Propan-1-ol & $0.102^{\mathrm{a}}$ & 4 & 0.025 & 11.048 & 0.001 & 0.815 & 0.742 \\
\hline Pentan-1-ol & $2.83^{\mathrm{a}}$ & 4 & 0.746 & 1.500 & 0.274 & 0.375 & 0.125 \\
\hline Hexan-1-ol & $6.448^{\mathrm{a}}$ & 4 & 1.612 & 155.603 & 0.000 & 0.984 & 0.978 \\
\hline Hexan-3-ol & $0.011^{\mathrm{a}}$ & 4 & 0.003 & 4.704 & 0.021 & 0.653 & 0.514 \\
\hline Dodecan-1-ol & $0.046^{\mathrm{a}}$ & 4 & 0.011 & 19.477 & 0.000 & 0.886 & 0.841 \\
\hline Hexandecan-1-ol & $3.790^{\mathrm{a}}$ & 4 & 0.948 & 45.081 & 0.000 & 0.947 & 0.926 \\
\hline Decan-1-ol & $0.001^{\mathrm{a}}$ & 4 & 0.000 & 0.225 & 0.919 & 0.082 & -0.285 \\
\hline Octan-1-ol & $0.021^{\mathrm{a}}$ & 4 & 0.005 & 5.804 & 0.011 & 0.699 & 0.579 \\
\hline 2,3-butandiol & $0.008^{\mathrm{a}}$ & 4 & 0.002 & 14.364 & 0.000 & 0.852 & 0.792 \\
\hline Isobutanol & $0.391^{\mathrm{a}}$ & 4 & 0.098 & 8.211 & 0.003 & 0.767 & 0.673 \\
\hline Gallic acid & $8523.516^{a}$ & 4 & 2130.879 & 2065.419 & 0.000 & 0.999 & 0.998 \\
\hline Protocatechuic acid & $459.449^{a}$ & 4 & 114.862 & 51.018 & 0.000 & 0.953 & 0.935 \\
\hline p-hydroxybenzoic acid & $2123.071^{a}$ & 4 & 530.768 & 66.326 & 0.000 & 0.964 & 0.949 \\
\hline Gentisic acid & $5791.319^{a}$ & 4 & 1447.830 & 2087.814 & 0.000 & 0.999 & 0.998 \\
\hline Vanillic acid & $79076.505^{\mathrm{a}}$ & 4 & 19769.126 & 54.676 & 0.000 & 0.956 & 0.939 \\
\hline Caffeic acid & $105205.014^{\mathrm{a}}$ & 4 & 26301.254 & 383.473 & 0.000 & 0.994 & 0.991 \\
\hline Clorogenic acid & $1.654^{\mathrm{a}}$ & 4 & 0.413 & 20.277 & 0.000 & 0.890 & 0.846 \\
\hline Syringic acid & $4.007^{\mathrm{a}}$ & 4 & 1.002 & 100.316 & 0.000 & 0.976 & 0.966 \\
\hline Epicatechin & $2.378^{a}$ & 4 & 0.595 & 6.677 & 0.007 & 0.778 & 0.619 \\
\hline p-coumaric acid & $0.756^{\mathrm{a}}$ & 4 & 0.189 & 4.906 & 0.019 & 0.662 & 0.527 \\
\hline Ferulic acid & $153.348^{a}$ & 4 & 38.337 & 2.971 & 0.074 & 0.543 & 0.360 \\
\hline Sinapic acid & $0.117^{\mathrm{a}}$ & 4 & 0.029 & 5.991 & 0.010 & 0.706 & 0.588 \\
\hline Trans-resveratrol & $6657.113^{\mathrm{a}}$ & 4 & 1664.278 & 3.162 & 0.064 & 0.558 & 0.382 \\
\hline Quercitin & $385.709^{a}$ & 4 & 96.427 & 3.142 & 0.065 & 0.557 & 0.338 \\
\hline
\end{tabular}

Table 6. Fragmentation table for the compounds identified in the analysed samples

\begin{tabular}{ccccc}
$\begin{array}{c}\text { Chemical } \\
\text { name }\end{array}$ & $\begin{array}{c}\mathrm{m} / \mathrm{z} \text { (ion } \\
\text { molar } \\
\text { mass })\end{array}$ & $\begin{array}{c}\text { quantifier } \\
\text { ion }(\mathrm{m} / \mathrm{z})\end{array}$ & $\begin{array}{c}1^{\text {st }} \text { qualifier } \\
\text { ion }(\mathrm{m} / \mathrm{z})\end{array}$ & $\begin{array}{c}2^{\text {nd }} \text { qualifier } \\
\text { ion }(\mathrm{m} / \mathrm{z})\end{array}$ \\
\hline $\begin{array}{c}\text { ethyl hexanoate } \\
\text { ethyl benzoate } \\
\text { ethyl palmitate }\end{array}$ & 144 & 88 & 43 & 99 \\
ethyl myristate & 284 & 105 & 77 & 122 \\
$\begin{array}{c}\text { ethyl } \\
\text { pentadecanoate }\end{array}$ & 270 & 88 & 101 & 43 \\
diethyl & 174 & 101 & 101 & 43 \\
succinate & 172 & 88 & 101 & 43 \\
ethyl octanoate & 200 & 88 & 101 & 55 \\
ethyl caprate & 103 & 45 & 43 & 75 \\
\hline ethyl lactate & & & & 57 \\
\hline
\end{tabular}

\begin{tabular}{ccccc}
\hline linanol & 154 & 71 & 93 & 55 \\
a-terpineol & 136 & 59 & 93 & 121 \\
geraniol & 154 & 69 & 41 & 68 \\
nerolidol & 204 & 41 & 69 & 43 \\
hotrienol & 91 & 71 & 82 & 43 \\
Propan-1-ol & 60 & 31 & 42 & 59 \\
Pentan-1-ol & 87 & 42 & 55 & 41 \\
Hexan-1-ol & 102 & 56 & 43 & 41 \\
Hexan-3-ol & 101 & 59 & 55 & 73 \\
Dodecan-1-ol & 168 & 55 & 43 & 69 \\
\hline Decan-1-ol & 157 & 70 & 55 & 56 \\
Octan-1-ol & 112 & 56 & 55 & 41 \\
\hline 2,3-butandiol & 90 & 45 & 43 & 57 \\
Isobutanol & 74 & 43 & 41 & 42 \\
\hline
\end{tabular}




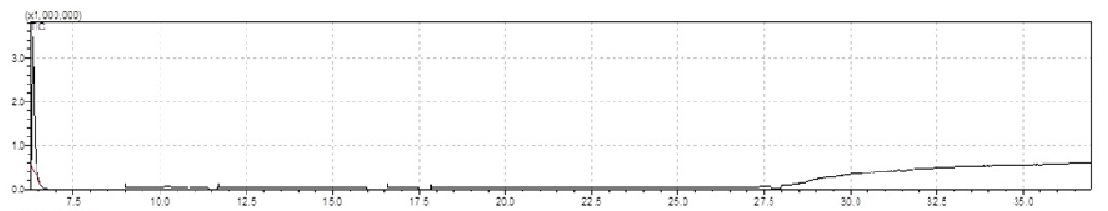

AO. Blank sample

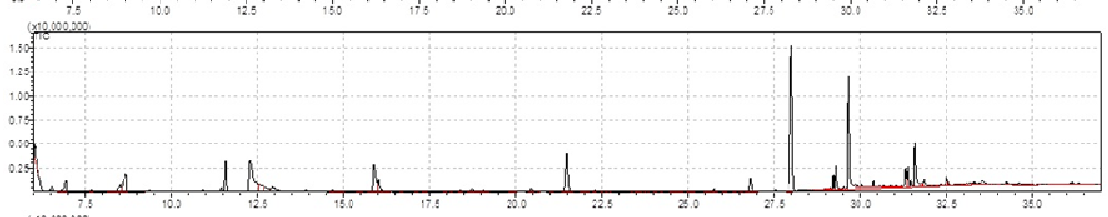

A1. FRVO-control sample

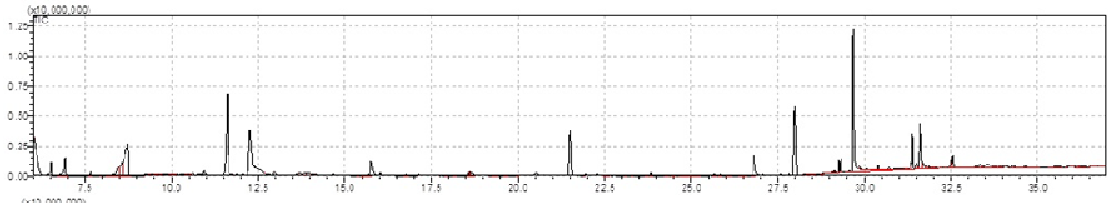

A2. FRV1- sample treated with bentonite

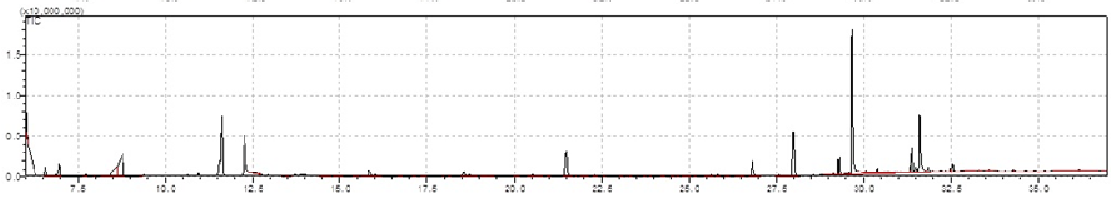

A3. FRV2- sample treated with glutathlone

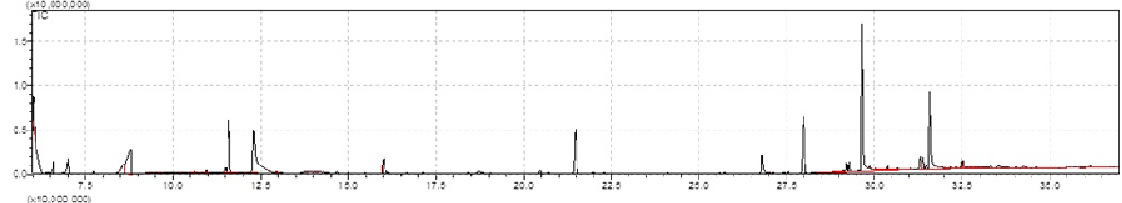

A4. FRV3-sample treated with tannins

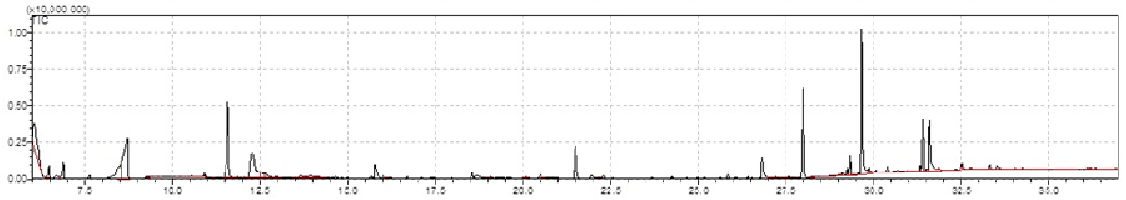

A5. FRV4- sample treated with clarlfylng enzymes

Fig. 6. Chromatograms of GC-MS analysis of the standard (A0) and wine samples (A1, A2, A3, A4, A5)

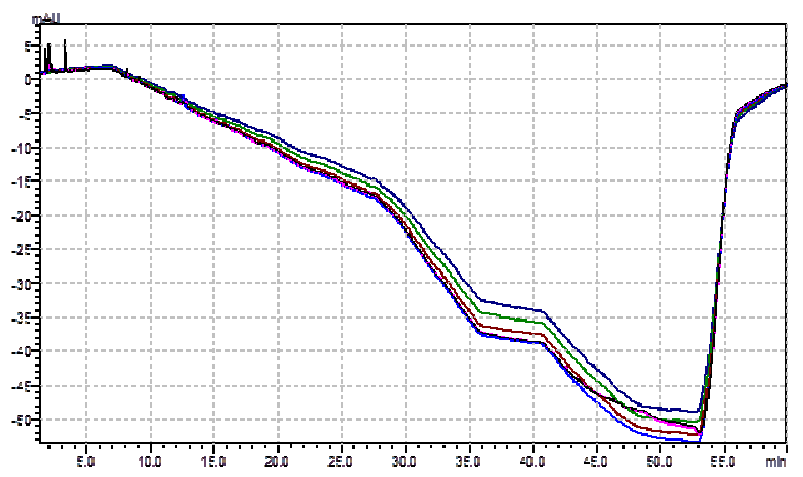

BO. Blank sample

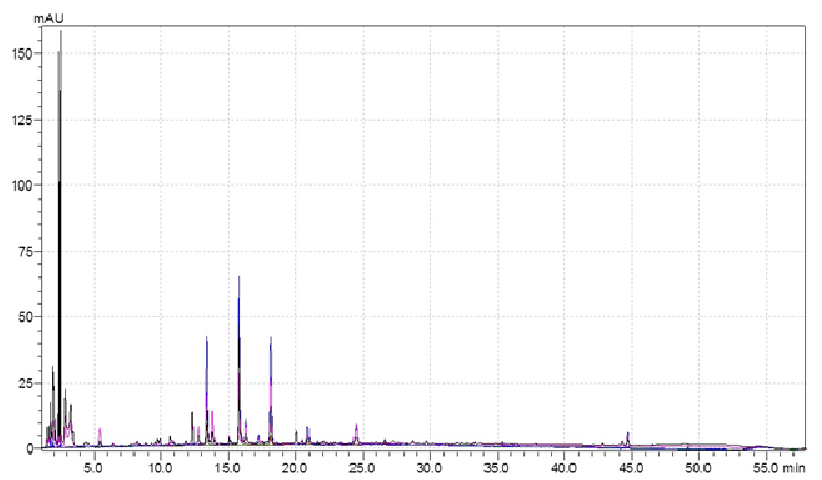

B2. FRV1- sample treated with bentonite

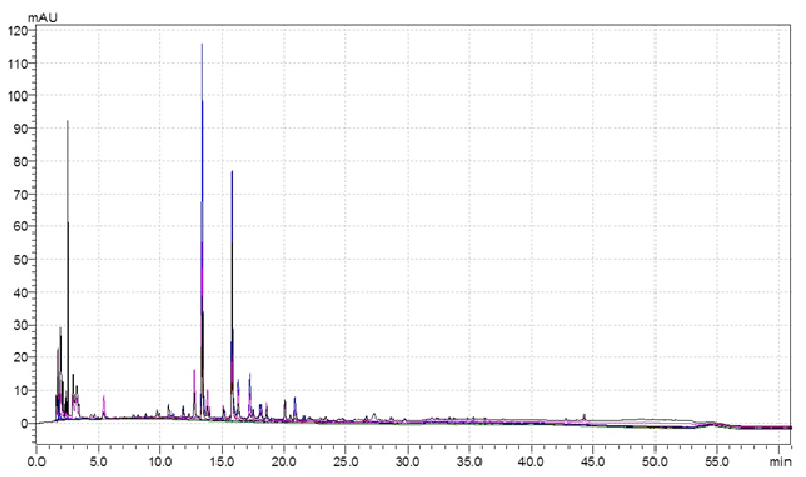

B1. FRVO- control sample

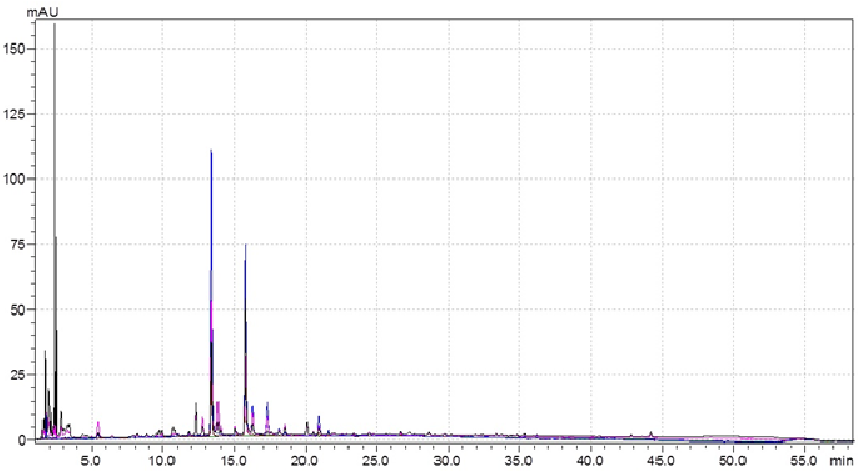

B3. FRV2- sample treated with glutathione 
256

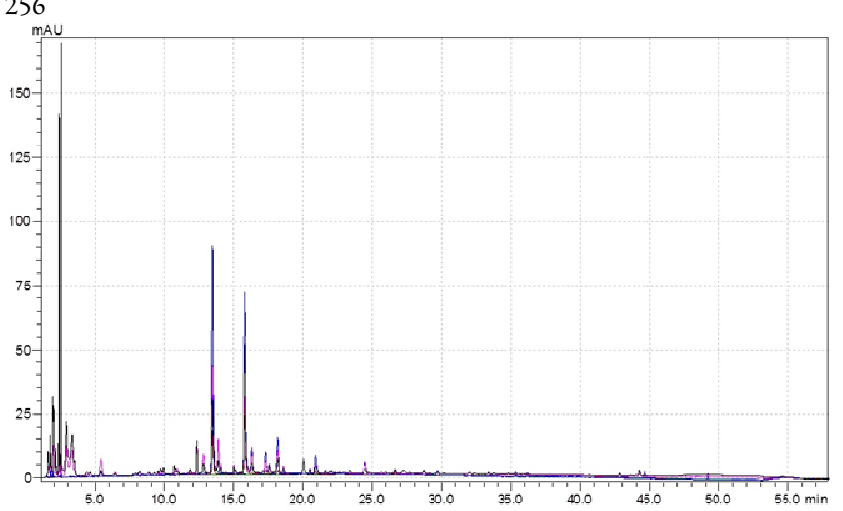

B4. FRV3-sample treated with tannins

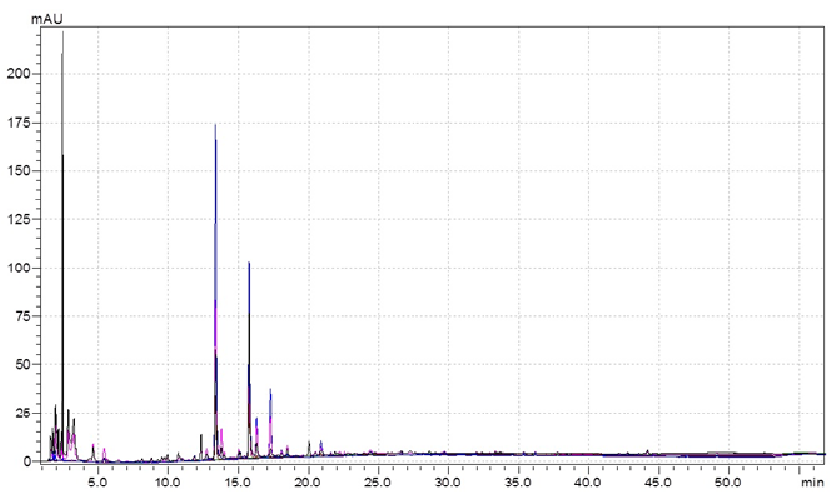

B5. FRV4- sample treated with clarifying enzymes

Fig. 7. Chromatograms of HPLC analysis of standard (B0) and wine samples (B1, B2, B3, B4, B5)

\section{Conclusions}

Thirty-eight compounds have been identified in the wine samples of 'Fetească regală' with the help of GC-MS analysis and HPLC analysis. According to the statistical analysis applied there were found results that were statistically significant. So the application of prefermentative treatments affected the quantitative variation of the alcohols, especially: ethyl benzoate, ethyl octanoate, ethyl palmitate, ethyl myristate, ethyl caprate and ethyl lactate. Also, the quantitative variation of some varietal aroma compounds such as: $\alpha$-terpineol, geraniol, nerolidol, ho-trienol, was influenced significantly by the treatments applied. The presence of alcohols it was influenced by the treatments applied, the exceptions would be pentan-1-ol and decan-1-ol. The phenolic compounds identified were influenced by the treatments, with the exception of ferulic acid, trans-resveratrol and quercitin were no significantly statistic results were found.

Referring to the sensorial analysis, differences following the application of pre-fermentative treatments were observed. Thereby, the application of glutathione treatments and clarifying enzymes determined the accentuation of green/vegetable flavours and also the green fruits flavours. Probably this effect is due to antioxidant activity of the glutathione that prevented the presence of oxidative processes. In the case of the clarifying enzymes treatments the amplification of the green/vegetable and green fruits flavours was probably due to the maceration process that allowed an intimate contact between seeds, skins and must. The mineral flavour has been intensified by the bentonite, glutathione and clarifying enzymes treatments. As expected the phenolic taste was better expressed in the last sample due to the fact that enzymes generally determine the quantitative increase of phenolic compounds. The acidity of the wines was in concordance with the values of the total acidity determined.

\section{References}

Allen MS, Lacey MJ, Boyd SJ (1994). Determination of methoxypyrazines in red wines by stable isotope dilution Gas Chromatography-Mass Spectrometry. Journal of Agriculture and Food Chemistry 42:1734 1738.
Amerine AM, Berg HV, Kunkee RE, Ough CS, Singleton VL, Webb AD (1980). The technology of winemaking. CT: AVI Technical Books Inc (4thed), Westport.

Amerine MA, Ough CS (1980). Alcohols: Methods for Wine and Must Analysis.John Wiley and Sons Inc, New York.

Antoce AO (2012). Study of the possibility of discrimination by an electronic nose of Fetească regală wines produced with neutral and aromatic yeasts. Scientific Papers, Series B, Horticulture Vol LVI:419426.

Antoce AO, Cojocaru GA (2015). Sensory profiles changes induced by the antioxidant treatments of white wines - the case of glutathione, ascorbic acid and tannin treatments on Fetească regală wines produced in normal cellar conditions. AgroLife Scientific Journal 6(1):19-30.

Blank I (1997). Techniques for Analyzing Food Aroma. Marsily R (Ed), New York

Berger RG (2007). Flavours and fragrances. Springer-Verlag Berlin Heidelberg, Germany

Camara JS, Herbert P, Marques JC, Alves MA (2004). Varietal flavour compounds of four grape varieties producing Madeira wines. Analytica Chimica Acta 513:203-207.

Cheynier V, Doco T, Fulcrand H, Guyot S, Le Roux E, Souquet JM, Rigaud J, Moutounet M ( 1997). ESI-MS analysis of polyphenolic oligomers and polymers. Analusis Magazine 25:32-37.

Cheynier V (2005). Polyphenols in food are more, complex than often thought. American Journal of Clinical Nutrition 81:223-229.

Dragone G, Mussatto SI, Oliveira JM, Teixeira JA (2009). Characterisation of volatile compounds in an alcoholic beverage produced by whey fermentation. Food Chemistry 112:929-935.

Ebeler SE, Spaulding RS (1998). Chemistry of Wine Flavor. Waterhouse AL, Washington DC.

Etiévant PX (1991). Wine. In: Maarse H(Ed). Volatile compounds in foods and beverages. New York: Marcel Dekker Inc.

Falqué E,Fernández E,Dubourdieu D(2001).Differentiation of white wines by their aromatic index. Talanta 54:271-281.

Feng Y,Liu M, Ouyang Y,Zhao X,Ju Y, Fang Y (2015). Comparative study of aromatic compounds in fruit wines from raspberry, strawberry, and mulberry in central Shaanxi area. Journal of Food and Nutrition Research 59:29290. 
Ferreira V, Lopez R, Aznar M (2001). Analysis of Taste and Aroma. Springer, Berlin.

Frankel EN, Waterhouse AL, Teissedre PL (1995). Principal phenolic phytochemicals in selected California wines and their antioxidant activity in inhibiting oxidation of human low-density lipoproteins. Journal of Agricultural and Food Chemistry 43:890-894.

Gatfield IL (1992). Bioreactors for industrial production of flavours: Use of enzymes. In: Patterson RLS, Charlwood BV, MacLeod G, Williams AA(Eds). Bioformation of flavours. The Royal Society of Chemistry pp 171-195.

Giudici P, Romano P, Zambonelli C (1990). A biometric study of higher alcohol production in Saccharomyces cerevisiae. Canadian Journal of Microbiology 36:61-64.

Guichard E, Pham TT, Etievant P (1993). Quantitative determination of sotolon in wines by high-performance liquid chromatography. Chromatographia 37:539.

Guth H (1997). Identification of character impact odorants of different white wine varieties. Journal of Agricultural and Food Chemistry 45:3022-3026.

Guth H (1997). Quantitation and sensory studies of character impact odorants of different white wine varieties. Journal of Agricultural and Food Chemistry 45:3027-3032.

Hui YH (2007). Handbook of food products manufacturing. John Wiley \&Sons Inc, Hoboken, New Jersey.

Jiang B, Zhang Z (2010). Volatile compounds of young wines from Cabernet Sauvignon, Cabernet Gernischet and Chardonnay varieties grown in the loess plateau region ofChina. Molecules 15:9184-9196.

Jordão AM, Ricardo-da-SilvaJM, Laureano O (2001).Evolution of catechin and procyanidin composition during grape maturation of two varieties (Vitis vinifera L,.) Castelão Francês and Touriga Francesa. American Journal of Enology and Viticulture 52:30-234.

Kilinc E, Kalkan H (2003). High-performance liquid chromatographic determination of some phenolic acids of Turkish commercial wines: an electrochemical approach. Journal of Wine Research 14:17-23.

Lambrechts MG, Pretorius IS (2000). Yeast and its importance to wine aroma - A review. South African Journal of Enology and Viticulture 21:97-129.

Margalit Y (1997). Concepts in wine chemistry. The Wine Appreciation Guild, San Francisco.

Martin B, Etievant PX, Quere J, Schlich P (1992). More clues about sensory impact of sotolon in some Flor Sherry wines. Journal of Agricultural and FoodChemistry 40:475-478.

Mestres M, Busto O, Guasch J (1998). Headspace solid-phase microextraction analysis of volatile sulphides and disulphides in wine aroma. Journal of Chromatography A 808:211-218.

Mestres M, Busto O, Guasch J (2000). Analysis of organic sulfur compounds in wine aroma. Journal of Chromatography A 881:569-581.
Minussi R C, Rossi M, Bologna L, Cordi L, Rotilio D, Pastore G M, Duran N (2003). Phenolic compounds and total antioxidant potential of commercial wines. Food Chemistry 82:409-416.

Moss R (2015). How higher alcohols and volatile phenols impact on key aromas. Oenology research, Winetech Technical.

Nykanen L (1986). Formation and occurrence of flavour compounds in wine and distilled alcoholic beverages. American Journal of Enology and Viticulture 37:84-96.

Oliveira JM, Faria M, Sa F, Barros F, Isabel M. Araujo IM (2006). C6alcohols as varietal markers for assessment of wine origin. Analytica Chimica Acta 563:300-309.

Orlić S, Arroyo-López FN, Huić-Babić K, Lucilla I, Querol A, Barrio E (2009). A comparative study of the wine fermentation performance of Saccharomyces paradoxus under different nitrogen concentrations and glucose/fructose ratios. Journal of applied Microbiology 108:73-80.

Ortega C, Lopez R, J. Cacho J, Ferreira V (2001). Fast analysis of important wine volatile compounds development and validation of a new method based on gas chromatographic-flame ionisation detection analysis of dichloromethane microextracts. Journal of Chromatography 931:205214.

Randhir R, Lin YT, Shetty K (2004). Phenolics, their antioxidant and antimicrobial activity in dark germinated fenugreek sprouts in response to peptide and phytochemical elicitors. Asia Pacific Journal of Clinical Nutrition 13:295--307.

Ribéreau-Gayon P, Glories Y, Maujean A, Dubourdieu D (2006). Handbook of enology. Vol 2: The chemistry of wine: Stabilization and treatments. 2ndEd. Chichester, Wiley.

Robinson J, Harding J (2015). The Oxford companion of wine. Oxford University Press, UK.

Slegers A, Angers P, Ouellet É, Truchon T, Pedneault K (2015). Volatile compounds from grape skin, juice and wine from five interspecific hybrid grape cultivars grown in Québec (Canada) for wine production. Molecules 20(6):10980-11016.

Schwarz M, Hofmann G, Winterhalter P (2004). Investigations on anthocyanins in wines from Vitis vinifera cv. Pinotage: factors influencing the formation of pinotin A and its correlation with wine age. Journal of Agricultural and Food Chemistry 52:498-504.

Teissedre PL, Landrault N (2000). Wine phenolics: contribution to dietary intake and bioavailability. Food Research International 33:461-467.

Tominaga T, Murat ML, Dubourdieu D (1998). Development of a method for analyzing the volatile thiols involved in the characteristic aroma of wines made from Vitis vinifera L. Cv. Sauvignon Blanc. Journal of Agricultural and Food Chemistry 46:10441048.

Tominaga T, Peyrot des Gachons C, Dubourdieu D (1998). A new type of flavor precursors inVitisvinifera L. cv. Sauvignon Blanc:s-cysteine conjugates. Journal of Agricultural and Food Chemistry 46:5215-5219. 
258

Annex 1. Aroma compounds identified in the analysed samples

\begin{tabular}{|c|c|c|c|c|}
\hline No & & Compound name & CAS & Odor descriptor \\
\hline 1 & \multirow{8}{*}{ 总 } & Ethyl hexanoate & $123-66-0$ & Sweet, fruity, pineapple, fatty, green banana \\
\hline 2 & & Ethyl benzoate & $93-89-0$ & Sweet, wintergreen, fruity, medicinal, cherry grape \\
\hline 3 & & Ethyl palmitate & $628-97-7$ & Fruity, creamy, milky, balsamic \\
\hline 4 & & Ethyl myristate & $124-06-1$ & Sweet, violet, orris \\
\hline 5 & & Diethyl succinate & $123-25-1$ & Fruity, apple, cooked apple, ylang \\
\hline 6 & & Ethyl octanoate & $106-32-1$ & Fruity, winey, sweet, apricot, banana, brandy, pear \\
\hline 7 & & Ethyl caprate & $110-38-3$ & Sweet, fruity, apple, grape, oily, brandy \\
\hline 8 & & Ethyl lactate & $97-64-3$ & Sweet, fruity, acidic, etherial with a brown nuance \\
\hline 9 & \multirow{5}{*}{ 岕 } & Linalool & $78-70-6$ & Citrus, floral, sweet, bois de rose, woody, green, blueberry \\
\hline 10 & & $\alpha$-terpineol & $98-55-5$ & Pine, terpenic, lilac, citrus, woody, floral \\
\hline 11 & & Geraniol & $106-24-1$ & Sweet, floral, fruity, rose, citrus \\
\hline 12 & & Nerolidol & $7212-44-4$ & Floral, green, waxy, citrus, woody \\
\hline 13 & & Ho-trienol & 20053-88-7 & Sweet, tropical, floral, fennel, ginger, spicy \\
\hline 14 & \multirow{11}{*}{$\begin{array}{l}\frac{n}{0} \\
\frac{\mathfrak{d}}{2}\end{array}$} & Propan-1-ol & $71-23-8$ & alcoholic fermented fusel tequila musty yeasty sweet fruity apple pear \\
\hline 15 & & Pentan-1-ol & $71-41-0$ & Fusel, oily, sweet, balsamic \\
\hline 16 & & Hexan-1-ol & $111-27-3$ & Ethereal, fusel, oily, fruity, alcoholic, sweet, green \\
\hline 17 & & Hexan-3-ol & $623-37-0$ & $\begin{array}{l}\text { Alcoholic solvent like, fusel notes of rum, egg nogg and whiskey, green } \\
\text { fruity nuances of guava and apple }\end{array}$ \\
\hline 18 & & Glycerol & $56-81-5$ & - \\
\hline 19 & & Dodecan-1-ol & $112-53-8$ & Earthy, soapy, waxy, fatty, honey, coconut \\
\hline 20 & & Hexandecan-1-ol & $36653-82-4$ & Waxy, floral \\
\hline 21 & & Decan-1-ol & $112-30-1$ & Fatty, floral, orange, sweet, clean, watery \\
\hline 22 & & Octan-1-ol & $111-87-5$ & Waxy, green, citrus, aldehydic and floral with a sweet, fatty, coconut nuance \\
\hline 23 & & 2,3-butandiol & $513-85-9$ & Fruity, creamy, buttery \\
\hline 24 & & Isobutanol & $78-83-1$ & Fusel, whiskey \\
\hline 25 & \multirow{14}{*}{ 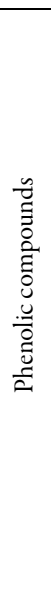 } & Gallic acid & $149-91-7$ & - \\
\hline 26 & & Protocatechuic acid & $99-50-3$ & Phenolic, balsamic \\
\hline 27 & & p-hydroxybenzoic acid & $99-96-7$ & Phenolic, nutty \\
\hline 28 & & Gentisic acid & $490-79-9$ & - \\
\hline 29 & & Vanillic acid & $121-34-6$ & Sweet creamy, phenolic, brown and powdery with vanilla beany nuances \\
\hline 30 & & Caffeic acid & $331-39-5$ & - \\
\hline 31 & & Clorogenic acid & $327-97-9$ & - \\
\hline 32 & & Syringic acid & $530-57-4$ & - \\
\hline 33 & & Epicatechin & $490-46-0$ & - \\
\hline 34 & & p-coumaric acid & $501-98-4$ & Balsamic \\
\hline 35 & & Ferulic acid & $537-98-4$ & - \\
\hline 36 & & Sinapic acid & $530-59-6$ & - \\
\hline 37 & & Trans-resveratrol & $501-36-0$ & - \\
\hline 38 & & Quercitin & $117-39-5$ & - \\
\hline
\end{tabular}


Annex 2. Wine tasting chart example

\begin{tabular}{|c|c|c|c|c|c|c|c|c|c|c|c|c|}
\hline & Name & & & & & & $\mathrm{sam}_{\mathrm{l}}$ & & & & & \\
\hline & Characteristics & & & & & & Not & & & & & \\
\hline & Ciralateristies & 0 & 1 & 2 & 3 & 4 & 5 & 6 & 7 & 8 & 9 & 10 \\
\hline & Green / Vegetable & & & & & & & & & & & \\
\hline & Mineral & & & & & & & & & & & \\
\hline & Citric & & & & & & & & & & & \\
\hline & Ripe fruits & & & & & & & & & & & \\
\hline : & Exotic fruits & & & & & & & & & & & \\
\hline$\tilde{\Xi}$ & Dried fruits & & & & & & & & & & & \\
\hline t & Green fruits & & & & & & & & & & & \\
\hline 总 & Haying & & & & & & & & & & & \\
\hline$\overline{0}$ & Wild flowers & & & & & & & & & & & \\
\hline & Spices & & & & & & & & & & & \\
\hline & Honey & & & & & & & & & & & \\
\hline & Rose & & & & & & & & & & & \\
\hline$\cong$ & Acidity & & & & & & & & & & & \\
\hline : & Sweet & & & & & & & & & & & \\
\hline ڤ్̆ & Bitter & & & & & & & & & & & \\
\hline 㻤 & Phenolic & & & & & & & & & & & \\
\hline$\stackrel{\pi}{g}$ & Onctuositaty & & & & & & & & & & & \\
\hline 5 & Texture (structure) & & & & & & & & & & & \\
\hline
\end{tabular}

